\section{Effect of Pregnancy and Lactation on Liver Vitamin A of Beef Cows Grazing Pangolagrass'}

\author{
W. G. KIRK, 2 J. F. EASLEY, R. L. SHIRLEY, AND E. M. HODGES \\ Animal Scientist, Assistant Animal Nutritionist, Animal Nutritionist, and \\ Agronomist, Range Cattle Experiment Slation, Ona and Animal \\ Science Department, Gainesville, Florida.
}

\section{Highlight}

The effect of pregnancy and lactation on vitamin $A$ and carotene in liver and plasma was determined for beef cows grazing pangolagrass. The cows averaged 13.4 years of age and had grazed pangolagrass continously as the only source of nutrients for an average of 9.5 years. Calves were weaned August 29, 1965, and cows were slaughtered December 8, 1965. Ten cows, nursing calves in 1965 and pregnant when slaughtered, had an average of 12.3 million $I$. $U$. equivalent vitamin $A$ in liver and plasma; seven cows, dry in 1965 and pregnant, had 20.9 million I. U.; three cows, nursing calves in 1965 and open, had 13.3 million I. U.; and one cow, dry in 1965 and open, had 24 million I. U. vitamin A. A well managed pangolagrass pasture in southcentral Florida furnished adequate carotene to meet the vitamin A needs of producing beef cows.

Vitamin A is essential for normal nutrition of beef cattle. National Research Council (1970) (NRG) state that a 1213 pound dry pregnant cow required $19,500 \mathrm{I}$. U. and a 1102 pound nursing cow, 41,000 I. U. vitamin A daily. The average daify vitamin A intake would be $30,250 \mathrm{I}$. U. for a cow weaning a calf each year. A level of 40,000 I. U. daily would insure a reserve of vitamin A to meet stress factors when they occur. The object of this paper was to determine the level of vitamin $\mathrm{A}$ and carotene in liver and plasma of beef cows which had obtained all their nutrients by grazing pangolagrass (Digitaria decumbens Stent.) for an average of 9.5 years.

Procedure and production results of seven herds of grade Brahman cows in a cow-calf project in a 15. year grazing trial were presented by Kirk et al. (1970a). Levels of vitamin $\mathrm{A}$ and carotene in liver and plasma from grazing cows and fed steers were compared by Kirk et al. (1970b) but the importance of these two tissues as storage depots was not determined. Highest values found were 4310 micrograms (mcg) vita-

${ }^{1}$ University of Florida Institute of Food and Agricultural Sciences, Journal Article No. 3936. Received April 10, 1971.

2 Animal Scientist Emeritus, Agricultural Research Center, Ona, Florida. min A per gram of dry liver and 1688 mcg carotene per 100 milliliter (ml) plasma. Low carotene values were zero per gram of liver and $\mathbf{9}$ mcg per $100 \mathrm{ml}$ plasma. It was shown that 20 pounds good quality air-dried pangolagrass forage daily per cow furnished 1100 milligrams (mg) carotene, equivalent to 440,000 I. U. vitamin A. This is several times in excess of the level recommended by NRC (1970) for a producing beef cow. NRC (1970) state that $1 \mathrm{mcg}$ vitamin $\mathrm{A}$ is equal to $3.3 \mathrm{I}$. U. and $1 \mathrm{mcg}$ carotene to 0.4 I. U. vitamin A.

Carpenter et al. (1961) found that livers of calves averaged $1.35 \%$ of their live weight. These authors in a private communication suggested that liver percentage decreases as live weight increases, giving a value of $1.25 \%$ for cows. Shirley et al. (1963) showed that fresh liver had about $28 \%$ dry matter. Using these values, liver dry matter would represent $0.35 \%$ of the slaughter weight for cows. According to Duke (1935) blood volume for a bullock by the wash out method was $7.7 \%$ of body weight, or $3.85 \%$ for blood plasma.

\section{Methods}

Twenty-one cows with an average age of 13.4 years selected from the seven herds of the original phos- phorus source trials were slaughtered on December 18, 1965. The pangolagrass grazed by the cows received $100 \mathrm{lb}$. $\mathrm{N}$, and $50 \mathrm{lb} . \mathrm{K}_{2} \mathrm{O}$ yearly, from 1955 to $1965 . \quad \mathrm{P}_{2} \mathrm{O}_{5}$ at the equivalent rate of $25 \mathrm{lb}$./acre was applied each year from 1955 to 1958 with no phosphorus applied from 1959 to 1965 . Four pastures permitted rotational and deferred grazing throughout the 11-year period.

The cows were classified into four groups according to their 1965 calving and pregnancy record and the data used for vitamin A study:

Group 1. 10 cows weaned calves in 1965 and pregnant.

Group 2. 7 cows dry in 1965 and pregnant.

Group 3. 3 cows weaned calves in 1965 and open.

Group 4. I cow dry in 1965 and open.

The cows except for short periods in late winter and early spring of 1958, 1960, and 1963 had adequate pangolagrass forage. Supplemental feed in these periods consisted of cottonseed hulls and citrus molasses, both devoid of vitamin A and carotene. Cows were given free access to common salt and modified salt sick mixture (Becker et al. 1953) but pasture forage was the only source of calcium and phosphorus.

Liver samples were obtained when cows were slaughtered. Samples were frozen until analyzed by the procedure of Gallup and Hoefer (1946) for vitamin A and A. O. A. C. (1960) method for carotene. Blood samples were citrated and iced until analyzed for vitamin $A$ and carotene by the method of Kimble (I939).

\section{Results and Discussion}

There was adequate pangolagrass forage on the ground to carry the cows through the winter when they were removed in December 1965. Samples of grass collected 2 to 4 times each year averaged on an airdried basis $5.22 \%$ crude protein and $0.27 \%$ phosphorus from 1955 to 1958, and $5.71 \%$ protein and $0.16 \%$ phosphorus from 1959 to 1965. 
Table 1. Vitamin $\mathbf{A}$ and carotene in liver and plasma of cows grazing pangola.

\begin{tabular}{|c|c|c|c|c|}
\hline \multirow[b]{2}{*}{ Item } & \multicolumn{4}{|c|}{ Group } \\
\hline & 1 & 2 & 3 & 4 \\
\hline No. cows & 10 & 7 & 3 & 1 \\
\hline Age (years) & 13.5 & 14 & 12 & 12 \\
\hline Grazing pangola (years) & 8.9 & 10.4 & 10.2 & 7 \\
\hline Cows weaned calves in 1965 & $5 \quad 10$ & 0 & 3 & 0 \\
\hline Cows pregnant on $12-8-65$ & 10 & 7 & 0 & 0 \\
\hline Slaughter weight (lb.) & 1181 & 1260 & 1168 & 1410 \\
\hline Carcass grade $^{1}$ & 6 & 7 & 6 & 8 \\
\hline Dry liver weight (g) & 1873 & 2000 & 1855 & 2236 \\
\hline Plasma volume (l) & 20.6 & 22.0 & 20.4 & 24.6 \\
\hline \multicolumn{5}{|l|}{ Vitamin A: } \\
\hline Dry liver (mcg/g) & 1957 & 3130 & 2149 & 3218 \\
\hline Plasma $(\mathrm{mcg} / 100 \mathrm{ml})$ & 20 & 17 & 24 & 20 \\
\hline Total $\left(\mathrm{mcg}^{2}\right)$ & $3.7 \overline{\mathrm{M}}^{4}$ & $6.3 \overline{\mathrm{M}}$ & $4.0 \overline{\mathrm{M}}$ & $7.2 \overline{\mathrm{M}}$ \\
\hline Total I.U. & $12.2 \bar{M}$ & $20.8 \overline{\mathrm{M}}$ & $13.2 \bar{M}$ & $23.8 \overline{\mathrm{M}}$ \\
\hline \multicolumn{5}{|l|}{ Carotene: } \\
\hline Dry liver $(\mathrm{mcg} / \mathrm{g})$ & 40 & 49 & 162 & 116 \\
\hline Plasma $(\mathrm{mcg} / 100 \mathrm{ml})$ & 960 & 1268 & 1006 & 1110 \\
\hline Total $\left(\mathrm{mcg}^{3}\right)$ & $2.3 \overline{\mathrm{C}}^{5}$ & $3.7 \overline{\mathrm{C}}$ & $3.1 \bar{C}$ & $5.3 \overline{\mathrm{C}}$ \\
\hline I.U. vitamin A & $0.9 \overline{\mathrm{C}}$ & $1.5 \overline{\mathrm{C}}$ & $1.2 \overline{\mathrm{C}}$ & $2.1 \overline{\mathrm{C}}$ \\
\hline $\begin{array}{l}\text { Total I.U. vitamin } A \text { in } \\
\text { liver and plasma }\end{array}$ & $12.3 \overline{\mathrm{M}}$ & $20.9 \overline{\mathrm{M}}$ & $13.3 \bar{M}$ & $24.0 \overline{\mathrm{M}}$ \\
\hline
\end{tabular}

Cow data and vitamin $\mathrm{A}$ and carotene level in liver and blood plasma of mature cows are summarized in Table 1 . The average slaughter weight for 21 cows was 1217 pounds, heavy for cows maintained on grass pasture in southcentral Florida. Condition of cows is indicated by the U. S. Commercial carcass grade and a shrunk carcass of $53.7 \%$. Slaughter weight was increased as 17 of the 21 cows were heavy with calf and dressing percentage decreased for the same reason.

The level of vitamin A per gram of dry liver ranged from an average of $1957 \mathrm{mcg}$ for the 10 cows in Group 1 to 3218 for the one cow in Group 4. Plasma carotene ranged from $960 \mathrm{mcg}$ per $100 \mathrm{ml}$ plasma for Group 1 to $1268 \mathrm{mcg}$ for Group 2.

$$
\begin{array}{lr}
\text { Vitamin A, liver } & 99.1 \% \\
\text { Vitamin A, plasma } & 0.1 \% \\
\text { Vitamin A, liver carotene } & 0.2 \% \\
\text { Vitamin A, plasma carotene } & 0.6 \% \\
\cline { 2 - 2 } \multicolumn{1}{c}{\text { Total }} & 100.0 \%
\end{array}
$$

The liver contained $99.3 \%$ and plasma $0.7 \%$ of the total vitamin A in these two tissues.

It is seen from Table 1 that the total I.U. vitamin $A$ in liver and

plasma in order of magnitude from low to high was: Group 1, 12.2 million; Group 3, 13.3 million; Group 2, 20.9 million; and Group 4, 24.0 million; the average for all groups was 15.7 million. These data indicate that giving birth and nursing a calf for approximately 7.5 months create a greater need for vitamin A than pregnancy and maintenance of a dry non-pregnant cow. The cows had an adequate reserve of vitamin A for (a) strcss periods, (b) unnatural low level of carotene in forage, or (c) extremely poor utilization of forage carotene, to meet the vitamin A requirements for an extended period. Average vitamin $\mathrm{A}$ in liver alone for the 21 cows could furnish 42,466 I.U. daily per cow for one year if all the stored vitamin could be utilized and no other source of carotene was available. These data show that wellmanaged pangolagrass can meet adequately the vitamin $A$ needs of beef cows with this forage as their only source of carotene.

\section{Literature Cited}

A. O. A. C. 1960. Official methods of analysis (9th Ed.) Ass. Offic. Agr. Chem., Washington, D. C.

Becker, R. B., P. T. Dix Arnold, W. G. KIRK, GeORge K. Davis, and R. W. KIDDER. 1953. Minerals for dairy and beef cattle. Fla. Agr. Exp. Sta. Bull. 513. 51 p.

Carpenter, J. W., A. Z. Palmer, W. G. Kirk, F. M. Peacock, and M. Koger. 1961. Slaughter and carcass characteristics of Brahman and BrahmanShorthorn crossbred steers. J. Anim. Sci. 20:336-340.

Dukfs, H. H. 1955. The physiology of the domestic animals. Comstock Publishing Associates. Cornell University Press. Ithaca, New York.

Gallup, W. G., and J. A. Hoeffer. 1946. Determination of Vitamin A in liver. J. Ind. Eng. Chem. Anal. 18:288.

Kimble, M. S. 1939. The photoelectric determination of vitamin $\mathrm{A}$ and carotene in human blood plasma. J. Lab. Clin. Med. 24:1055-1065.

Kirk, W. G., R. L. Shirley, E. M. Hodges, G. K. Davis, F. M. Peacock, J. F. Easley, and F. G. Martin. 1970a. Production performances and blood and bone composition of cows 
grazing pangolagrass pastures receiving different phosphate fertilizer. Fla. Agr. Exp. Sta. Tech. Bull. 735. $55 \mathrm{p}$.

KIRK, W. G., R. L. Shirley, J. F. EAsley, and F. M. Peacock. $1970 \mathrm{~b}$.

Vitamin $\mathbf{A}$ and B-carotene in liver and blood of cows grazing pangolagrass. J. Range Manage. 23:136-139.

NUTRIEN'T REQUIREMENT OF BEEF CATTLE. 1970. Nat. Res. Council National Academy of Sciences. Washington, D. C. $55 \mathrm{p}$.

Shirley, R. L., D. D. HARgrove, Flora
Palting, J. F. Easley, J. W. CarPENTER, AND MARVIN Koger. 1963. Water, phosphorus, calcuim, ash and protein of the heart, liver and muscle of Hereford, Brahman and Hereford-Brahman crossbred cattle. J. Anim. Sci. 22:393-395. 